\title{
15. The economic case against the marginalisation of migrant workers in Malaysia
}

\author{
Theng Theng Tan and Jarud Romadan Khalidi
}

The plight of migrant workers in many countries has been in the spotlight since the beginning of the global COVID-I9 outbreak. Owing to their low-income, precarious jobs and poor living standards, migrant workers became one of the most vulnerable populations amid the pandemic.

Migrant workers in Malaysia were no exception. In 2020, there were at least two million migrant workers, mostly from Indonesia and Bangladesh, making up $14 \%$ of Malaysia's total employed persons (DOSM 202I; MOHA 2020). Many were known to live in overcrowded accommodation in unsanitary conditions, either provided by unscrupulous employers or sourced by workers themselves, making it impossible to maintain good hygiene and practise physical distancing during the pandemic. Moreover, the Malaysian Trades Union Congress also reported violations of migrant workers' rights by their employers during the pandemic. This included unfair terminations, unpaid wages, workers being required to continue working in non-essential jobs, and workers' uncertainty about their employment status due to limited contact with employers (ILO 2020). Those who lost their jobs would have also lost their work passes, making them undocumented and at risk of being arrested.

Unfortunately, the Malaysian government did little to address the vulnerabilities faced by these workers. Although the government gazetted the Workers' Minimum Standard of Housing and Amenities Bills, which require all employers to provide standard accommodation to their migrant workers, this took place only in August 2020, and most employers were unable to comply with the regulation immediately, especially in a difficult economic climate (Straits Times 2020c). Overall, fewer than I०\% of documented migrant workers lived in regulation-compliant housing by December 2020 (Bernama 2020).

How to cite this book chapter:

Tan, Theng Theng; and Khalidi, Jarud Romadan. 2022. 'The economic case against the marginalisation of migrant workers in Malaysia'. In: Shin, Hyun Bang; Mckenzie, Murray; and Oh, Do Young (eds) COVID-I9 in Southeast Asia: Insights for a post-pandemic world. London: LSE Press, pp. I72-1 82.

DOI: https://doi.org/I0.3I389/lsepress.cov.o License: CC BY 4.0. 
Furthermore, when major immigration raids took place in May 2020 to detain undocumented workers, concerns were raised that more migrant workers would have been scared into hiding, making testing and treatment, as well as tracing the spread of coronavirus, even more challenging (Straits Times 2020b). Given migrant workers' precarious living conditions, the government's actions did little to contain migrant workers' exposure to coronavirus. It is no surprise that, by the end of 2020 , migrants accounted for more than $40 \%$ of all confirmed COVID-I 9 cases in Malaysia, despite constituting only ı०\% of the country's population (MOH 2020; authors' calculation).

On the job front, government assistance was lacking as well. One of the most prominent initiatives was a $25 \%$ cut for the migrant worker levy due between April and December 2020 to alleviate the financial burden on hard-hit small- and medium-sized enterprises. Unfortunately, this was likely not helpful as the levy cut amounted to discounts of only I03-463 Malaysian ringgit, roughly US\$25-II5, per worker (Tan, Nazihah, and Jarud 2020). Even after restrictions on movement were gradually lifted, the government repeatedly urged employers to prioritise locals in their hiring practices as part of measures to alleviate soaring unemployment among Malaysians. This policy was also justified as an effort to wean Malaysia off its reliance on low-wage migrant workers and encourage automation in the long run (Minderjeet 2020).

In a global public health and economic crisis, it is only humane to treat everyone with care and dignity, regardless of nationality or social class. Migrant workers deserve protection by the simple virtue that they are human, and basic protection should be part of their human rights. Unfortunately, human rights arguments often fall on deaf ears, with many still calling for governments to prioritise their citizens over migrants.

However, even from a pure economic perspective, an ideology that puts the welfare of citizens first must give way to inclusive protection measures. Although some may argue that, given limited resources, governments have an obligation to prioritise their citizens over migrants, there are several strong economic arguments against the marginalisation of migrant workers.

\section{Neglecting migrant workers hurts locals too}

The pandemic laid bare the pervasiveness of economic externalities beyond what was previously thought. In the case of migrant workers in Malaysia, the economic consequences of neglecting their welfare manifested in at least two ways. 
First, the failure to manage migrant workers' exposure to coronavirus strained the public healthcare system and led to the extension of movement restrictions. In November 2020, a cluster linked to the migrant workers at Top Glove Corp's congested dormitories became the largest COVID-I9 cluster in Malaysia as of April 202I (Malaysiakini 202 I; Straits Times 2020a). After more than 3,000 workers tested positive within a month, coronavirus spread beyond the workers' circle to the community, forced the company to shut its factories, and caused the area to be placed under an extended period of lockdown (Hazlin 2020; Teh and Dhesegaan 2020). On a national scale, by early January 202 I, the number of confirmed locally transmitted cases among non-citizens had risen drastically by more than 30,000 . This contributed to the pressure that eventually brought the country's healthcare system to 'breaking point', forcing the government to lengthen movement restrictions within the country (Ahmad 202I). Clearly, any outbreak - whether involving poor migrant workers or rich Malaysians - would indiscriminately affect the larger population by straining the public healthcare

Figure 15.1. Migrant workers are important to Malaysia's economy

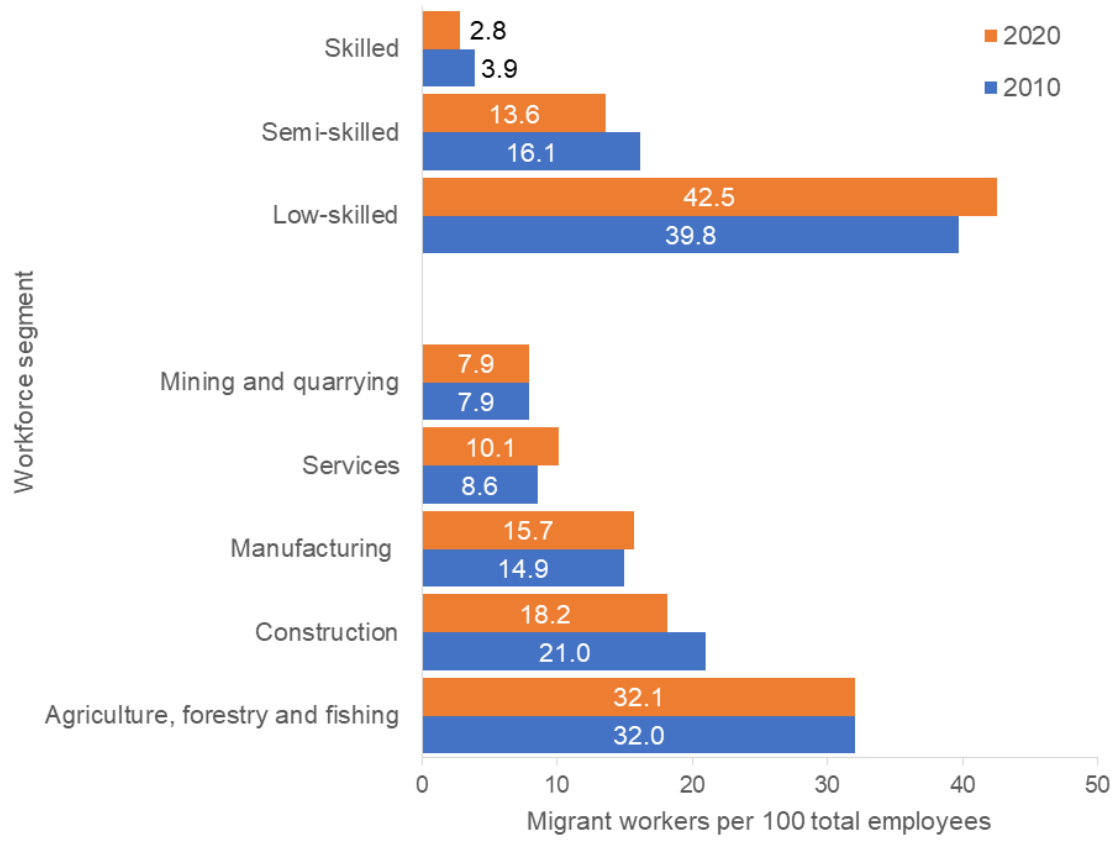

Source: DOSM (20II), DOSM (20I 5), DOSM (202I) and authors' calculation.

Note: Migrant workers made up a large proportion of workers in different sectors and among the low-skilled workers. 
system and throwing more businesses into deeper waters as lockdown became inevitable.

Second, in terms of migrant workers' job security, inadequate support to protect workers' jobs also had a spillover effect on the survival of industries and businesses. Malaysia's economy had long been heavily reliant on the migrant workforce. In 2020, migrant workers made up more than $30 \%$ of the workforce in the agriculture sector, and just below $20 \%$ in both the construction and manufacturing sectors (Figure I 5.I). Almost half of the low-skilled workers in Malaysia were of foreign origin. For semi-skilled jobs, where the majority of jobs were, more than one in Io were migrant workers. Overall, an estimated $22 \%$ of establishments in Malaysia hired migrant workers in 2018 (MOHR 20I9).

As such, without adequate support to protect migrant workers' jobs, Malaysia effectively unplugged its economy's access to a large swathe of the labour force. This served an extra blow to businesses that were already grappling with the economic consequences of the pandemic. As firms struggled to stay afloat, this in turn complicated the effort to reduce unemployment.

\section{The difference between migrant and local workers}

When migrant workers became absent from the labour market whether due to sickness or job loss - hiring local workers to replace them was not easy simply because migrant and local workers are not perfect substitutes.

Between 2010 and 2020, most of the migrant workers who entered the labour market had at most a secondary education (Figure I 5.2). By contrast, the Malaysian labour force was becoming more educated: there were fewer people with only a primary education or less and over two million more who were tertiary educated. This partly explains why, within the same decade, most migrant workers tended to go into lower-skilled jobs, whereas Malaysians were mostly hired in skilled and semi-skilled occupations.

In other words, given their distinct education profiles, migrant and local workers generally do not do the same jobs. Lower-educated migrant workers often take on lower-skilled jobs that are deemed dirty, dangerous, and difficult $\left.{ }_{3} \mathrm{D}\right)$, which are also jobs that Malaysians usually shun. Indeed, in a survey conducted by the Malaysian Employers Federation (MEF), around $78 \%$ of IOI member companies reported that the main reason for recruiting migrant workers was a 'shortage of local workers to fill vacancies' (MEF 20I4). Although this survey was 


\section{Figure 15.2. Migrant and local workers occupied different occupational spaces}

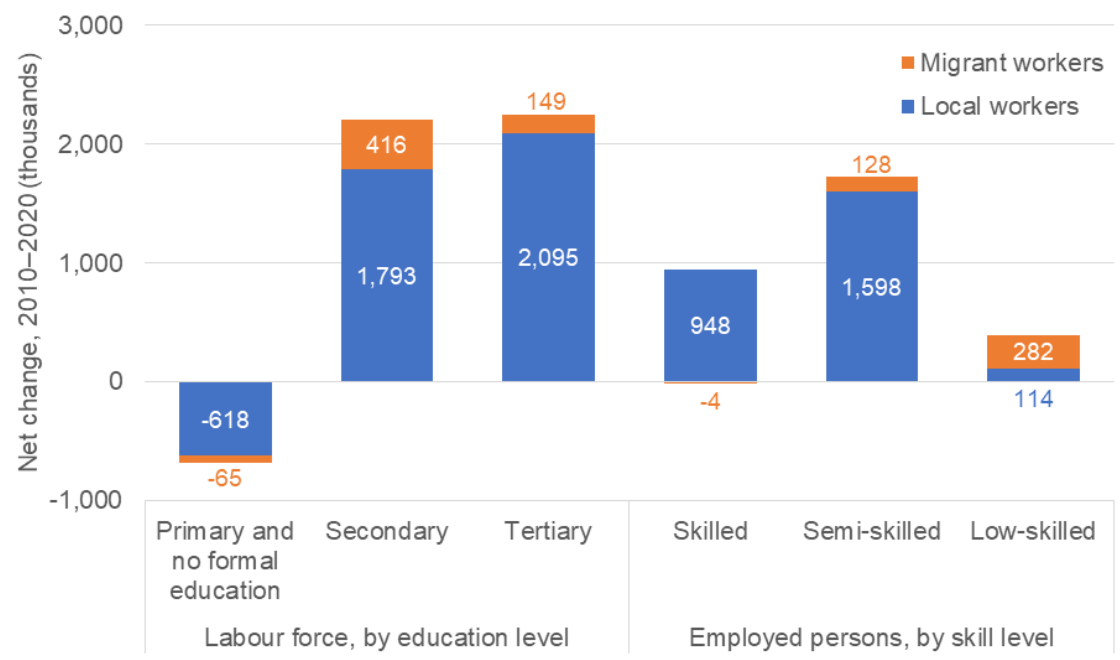

Sources: DOSM (20II), DOSM (20I 5), DOSM (202I) and authors' calculation. Note: Between 2010 and 2020, migrant workers mostly went into low-skilled occupations due to their lower education backgrounds.

not nationally representative, it gives a broad sense of the struggle that firms faced in hiring local workers.

Therefore, by neglecting migrant workers' health and requiring employers to hire only local workers after lockdown, the government was putting employers in a challenging position. For example, following the government's directive to stop hiring migrant workers, market traders at wholesale and wet markets in Selangor found it hard to hire (Soo 2020). The jobs that migrant workers did were often too demanding for locals, such that it took two locals to handle one migrant worker's workload. As such, the market functioned at less than $20 \%$ of its full capacity due to the staffing disruption.

Encouragingly, after a petition by some employers, the government announced in August 2020 that employers could hire migrant workers who had previously been laid off. This was indeed a move in the right direction. After all, migrant and local workers had been occupying different occupational spaces. Expecting this to change overnight - even amid a global economic crisis - was unrealistic.

\section{The march towards automation}

Last but not least, the pathway to a successful structural transformation of the economy that will benefit all Malaysians does not depend 
solely on reducing Malaysia's reliance on migrant workers. Although there has been a wealth of economic research on the short-term impact of immigration on the employment and wages of locals, immigration's long-term effects on Malaysia's choice of production technology and the growth potential of its economy have remained under-investigated. One view holds that current low-cost, labour-intensive production strategies - made possible by the relative abundance of migrant workers - may actually have been slowing down Malaysia's adoption of the latest forms of technology (KRI 20I 8; $\mathrm{Ng}$, Tan, and Tan 20I8). If true, this has significant implications for Malaysia's ability to sustain its economic development and eventually transition to an advanced economy. ${ }^{\mathrm{I}}$

Without a doubt, this is a highly consequential research question. Yet it does not imply that removing migrant workers from the labour market would automatically promise a structural transformation of Malaysia's economy that guarantees prosperity and employment security for all. First and foremost, it is naïve to assume that firms would simply upgrade their technology once low-skilled migrant workers are absent from the labour market. For one thing, labour-saving technologies are costly. The adoption of automation or the relocation of production to overseas locations with low-cost labour are luxuries that are often exclusive to large firms only, while other firms might go out of business instead (Sumption and Somerville 2009). This is pertinent in light of the fact that, in $2016,90 \%$ of Malaysian manufacturing firms had fewer than 75 employees each (DOSM 20I7). It forces the question of how Malaysia can ensure these firms remain competitive in the face of global technological advancement so that the manufacturing sector can continue to be a reliable source of job creation.

From the workers' perspectives, automation and new technology are bound to replace jobs, and it is Malaysians, not migrant workers, who are at the highest risk of job displacement. Based on findings by KRI (20I7a), in the next two decades, $54 \%$ of all jobs in Malaysia could be displaced by technology. Four in five of these high-risk jobs are semi-skilled jobs. Malaysians will be most affected because $86 \%$ of all semi-skilled jobs are held by Malaysians. In fact, the hollowing-out of semi-skilled jobs by technology has been evident since $200 \mathrm{I}$ (Figure I 5.3). The void is only expected to deepen further with rapid progress in technology, more so if the government fully commits itself to the transformation of the country's economic model.

Clearly, the road to economic transformation comes with its own set of labour and industrial challenges that will inevitably put Malaysians' 
Figure 15.3. The disappearing middle - percentage point changes in employment share between $200 \mathrm{I}$ and 2020

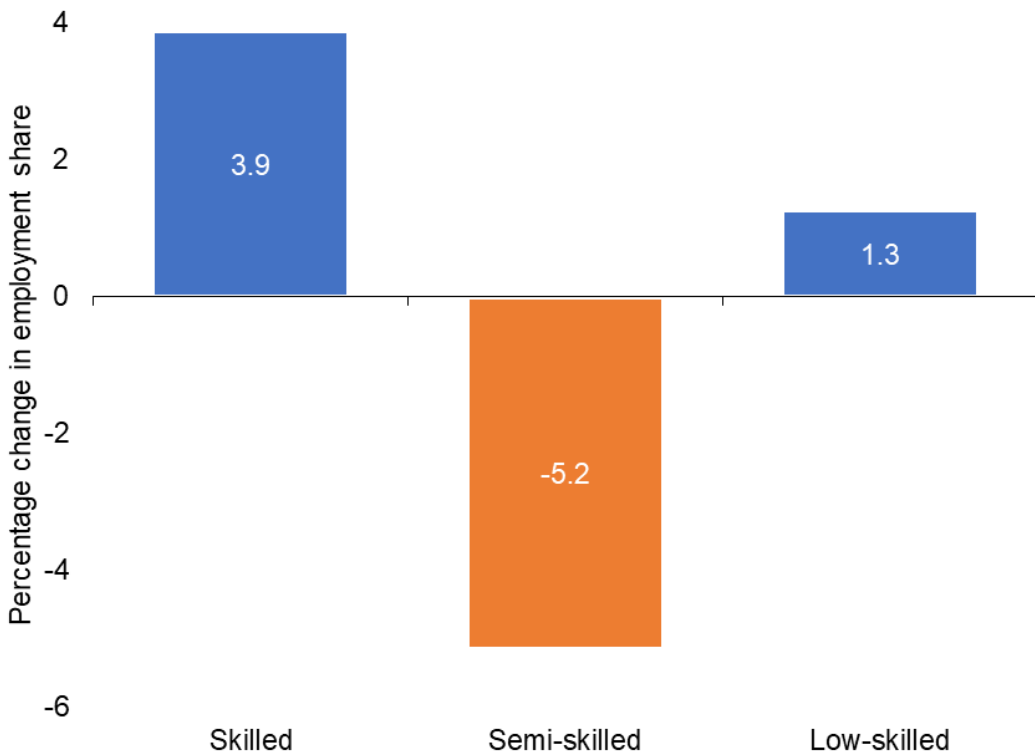

Sources: DOSM (n.d.), DOSM (202I) and authors' calculation.

Note: Unlike jobs on both ends of the skills spectrum, semi-skilled jobs experienced a dip between $200 \mathrm{I}$ and 2020.

jobs at risk. Reducing Malaysia's reliance on migrant workers could be an important policy lever to drive transformation, but it is a foundation of sound labour, industrial, and education policies that will ensure the sustainable creation of quality jobs and prepare all Malaysians for the rapidly evolving employment landscape. This may involve, among other things, strengthening public-private interactions to better inform industrial policies to create an enabling environment for innovation, developing active labour market policies to continually retrain the workforce, and reforming the education system to equip all Malaysians with relevant skills for the future (KRI 20I7a; Rodrik and Sabel 2020). As far as employment security is concerned, the question is: has Malaysia invested enough in building the foundation?

\section{Conclusion - becoming better, together}

If there is anything that the pandemic has taught us, it is that we are all in this together, and only by caring for one another can we emerge from the crisis safe and strong. From this chapter, it should be clear that neglecting migrant workers incurs significant economic externalities 
that inevitably hurt the greater population. Furthermore, amplifying the urgency to reduce the reliance on migrant workers in a time like this has only distracted the country from what needs to be fundamentally improved in order to transform Malaysia's economy in the medium to long term.

Nonetheless, economic arguments should not be the only consideration when it comes to the ways in which we treat others. Certainly, the population of migrant workers - whether documented or otherwise - who have contributed significantly to Malaysia's economy are owed a duty of care. Besides stepping up job protection for all migrant workers during the pandemic, Malaysia must commit to protecting migrant workers' rights at all times. This includes overhauling existing regulations to safeguard workers' undisputed access to healthcare services and decent living conditions and holding employers and all authorities along the migrant workers' employment line accountable for any form of mistreatment of workers. These should apply in any other countries that host migrant workers, because how we treat migrant workers will determine not only the fate of our societies but also how our countries are remembered in the annals of history.

\section{Note}

I. This section draws from the research findings of KRI (20I7a) and KRI (20I7b), two of the few studies in Malaysia that thoroughly investigate the impact of automation on the Malaysian employment landscape.

\section{Acknowledgements}

This chapter draws from the discussion in Tan, Nazihah, and Jarud (2020), a discussion paper that explains at length the practicality of protecting migrant workers in Malaysia. The authors are grateful for the valuable comments by Allen Ng, Nazihah Mohamad Noor, and Ryan Chua. All errors remain those of the authors.

\section{References}

Ahmad, Naqib Idris. (202I). 'PM: Nation's healthcare system is at breaking point'. The Edge, I I January. https://perma.cc/BT8J-VWXE [Last accessed I3 January 202I].

Bernama. (2020). 'Saravanan: Accommodation for over 90\% of foreign workers in Malaysia not in compliance with Act 446'. The Edge, 3 
December. https://www.theedgemarkets.com/article/saravanan-accommodation-over-9o-foreign-workers-malaysia-not-compliance-act-446 [Last accessed I3 January 202I].

DOSM (Department of Statistics Malaysia). (20II). Labour Force Survey Report 20I0. Malaysia: Department of Statistics Malaysia.

DOSM. (201 5). Labour Force Survey Report 2015. Malaysia: Department of Statistics Malaysia.

DOSM. (20I7).Economic Census 20 I 6: Manufacturing. Malaysia: Department of Statistics Malaysia.

DOSM. (202I). Labour Force Survey Report 2020. Malaysia: Department of Statistics Malaysia.

DOSM. (n.d.) Labour Force Survey (LFS) Time Series Statistics by State, I982-2019. Malaysia: Department of Statistics Malaysia. https://perma.cc /M5DH-BEFQ [Last accessed I 3 January 202I].

Hazlin, Hassan. (2020). 'World's biggest glove maker shuts 28 Malaysia factories after Covid-I9 infections'. Straits Times, 23 November. https://perma .cc/4JGB-KWTP [Last accessed I 3 January 202 I] .

ILO (International Labour Organization). (2020). COVID-I9: Impact on Migrant Workers and Country Response in Malaysia. Switzerland: International Labour Organization. https://perma.cc/4DPW-MELH [Last accessed I3 January 202I].

KRI (Khazanah Research Institute). (20I7a). The Times They Are a-Changin': Technology, Employment, and the Malaysian Economy. Malaysia: Khazanah Research Institute. https://perma.cc/9EVS-EPA9 [Last accessed I3 January 202I].

KRI. (20I7b). An Uneven Future? An Exploration of the Future of Work in Malaysia. Malaysia: Khazanah Research Institute. https://perma.cc/HYK4 -RUN5 5 [Last accessed I3 January 202I].

KRI. (20I8). The State of Households 20I8: Different Realities. Malaysia: Khazanah Research Institute. https://perma.cc/NTP $3-\mathrm{WCK}_{7}$ [Last accessed 29 April 202I].

Malaysiakini. (202I). Covid-I9 in Malaysia, 28 April. https://perma.cc/U6U3 -P76G [Last accessed 29 April 202I].

MEF (Malaysian Employers Federation). (2014). Practical Guidelines for Employers on the Recruitment, Placement, Employment and Repatriation of Foreign Workers in Malaysia. Malaysia: Malaysian Employers Federation. https://perma.cc/7K 3 T-8 5 X8 [Last accessed I3 January 202 I]. 
Minderjeet, Kaur. (2020). 'Rethink foreign worker policies now, govt told as massive job losses loom'. Free Malaysia Today, 24 April. https://perma.cc /WBZ6-VX2B. [Last accessed I3 January 202I].

MOH (Ministry of Health). (2020). 'Situasi Terkini COVID-ı9 di Malaysia 3I Disember 2020', 3 I December. https://perma.cc/2UUL-HUL4 [Last accessed I3 January 202I].

MOHA (Ministry of Home Affairs). (2020). Statistik pekerja asing mengikut negara dan tahun. Malaysia: MOHA. https://perma.cc/FW89-DE8A [Last accessed I3 January 202I].

MOHR (Ministry of Human Resources). (2019). National Employment Returns (NER) 20I8. Malaysia: MOHR. https://perma.cc/6 $\mathrm{NN}_{5}-\mathrm{Y}_{5} \mathrm{~W}_{2}$ [Last accessed I3 January 202I].

Ng, Allen; Tan, Theng Theng; and Tan, Zhai Gen. (2018). What Explains the Increase in the Labor Income Share in Malaysia? Japan: Asian Development Bank Institute Working Paper 894. https://perma.cc/DY2H-VTFE [Last accessed 29 April 202I].

Rodrik, Dani; and Sabel, Charles. (2020). Building a Good Jobs Economy. UK: HKS Faculty Research Working Paper Series RWP2O-ooI.

Soo, Wern Jun. (2020). 'Told not to hire migrant workers, market traders in KL struggle to handle business on their own'. Malay Mail, I 8 May. https:// perma.cc/746U-BTES [Last accessed I 3 January 202I].

Straits Times. (2020a). 'Malaysia's Top Glove confirms first worker death from Covid-r9', I4 December. https://perma.cc/VPA7-25ZS. [Last accessed I3 January 202I].

Straits Times. (2020b). 'Malaysia detains hundreds of foreign workers in major raid on KL Wholesale Market'. I I May. https://perma.cc/PU23-5UGK [Last accessed I3 January 202I].

Straits Times. (2020c). 'Malaysia employers plead for time to provide standard accommodation for foreign workers'. 7 September. https://perma.cc /WHT6-78XU [Last accessed I3 January 202 I].

Sumption, Madeleine; and Somerville, Will. (2009). Immigration and the Labour Market: Theory, Evidence and Policy. USA: Migration Policy Institute. https://perma.cc/4G8M-336K [Last accessed I 3 January 202 I].

Tan, Theng Theng; Nazihah, Muhamad Noor; and Jarud, Romadan Khalidi. (2020). Covid-19: We Must Protect Foreign Workers. Malaysia: Khazanah Research Institute. https://perma.cc/C8MU-F64J [Last accessed I 3 January 202I]. 
Teh, Athira Yusof; and Dhesegaan, Bala Krishnan. (2020). 'Teratai cluster: "The virus has spread beyond factory workers' circle"'. New Straits Times, 23 November. https://perma.cc/7CHF-4ZUL [Last accessed I3 January 202I]. 